\title{
The Urgency of a Legal Protection on Equity Crowdfunding Services Based on the Regulation of the Indonesian Financial Service Authority No. 57/POJK.04/2020
}

\author{
Wardah Yuspin; Nur Rohmah Wati \\ Universitas Muhammadiyah Surakarta, Indonesia \\ http://dx.doi.org/10.18415/ijmmu.v9i2.3536
}

\begin{abstract}
A crowdfunding service that is carried out through information technology-based stocks or commonly known as equity crowdfunding is an innovation in the development of the digital economy. It is a supporting factor of Indonesia's economic development as stipulated in the Regulation of the Financial Service Authority (RFSA) No. 37/POJK.04/2018. In 2020, this regulation was perfected into RFSA No. 57/POJK.04/2020 concerning the crowdfunding activity expansion, starting from the issuer to the stock. In RFSA No.57/POJK.04/2020 there was a transitional provision that became a problem for equity crowdfunding service program organizers in expanding their business according to RFSA No.57/POJK.04/2020. It concerns the grace period and the revocation of the permit by the Financial Service Authority if the organizers fail to reregistered during the determined grace period, though in expanding the business activity, there needs to be a profound analysis to prevent users from experiencing loss. This limited grace period certainly brings loss to the organizers, thus there needs to be a solution to keep the crowdfunding services running. Because of that, this research analyses the transitional provision in the RFSA No.57/POJK.04/2020 concerning equity crowdfunding in Indonesia. This paper uses the normative approach with a literature review analysis. The results are presented qualitatively. Research results show that there needs to be an additional grace period in the transitional provisions so organizers have enough time to undergo analyses in expanding their business activities. This is to prevent organizers or users from experiencing losses in the future.
\end{abstract}

Keywords: Equity Crowdfunding; Organizer; Crowdfunding Service; Transitional Provisions; Grace Period

\section{Introduction}

The current industrial revolution $4.0^{1}$ is characterized by the worldwide rapid and extensive advancement of information and digital technologies. This may create change that may attract the interest and the attention of many people. The development of digital technologies affects people's social lives,

\footnotetext{
1 Badan Penelitian dan Pengembangan SDM Puslitbang Aptika dan IKP, "PERKEMBANGAN EKONOMI DIGITAL DI INDONESIA, STRATEGI DAN SEKTOR POTENSIAL(The development of digital economy in Indonesia, strategy and potential sectors)", KOMINFO, 2019, Hal. 1, accessed on https://balitbangsdm.kominfo.go.id/publikasi_665_3_230, 20 August 2021.
} 
including their mindsets and consumption patterns - creating new traditions. This greatly affects the life of the millennial generation, as not only do they use it in the context of communication and in finding or exploring data or news, but they also affect their business or investment patterns. This shows that the people are enthusiastic about supporting economic development in the digital era. According to Encarta Dictionary, the digital economy is shown by the rampant business transactions via the internet with extensive use of information technologies, including software, hardware, applications and telecommunication in every economic aspect. ${ }^{2}$ In increasing the economy that depends on digital technologies, the government must make efforts to change the previous economy that depended on the export of commodities and the consumption sector to become investment-based economic growth.

The innovations in the digital era are without boxes, out of the box, and unlimited. ${ }^{3}$ One of the concrete forms of innovation is equity crowdfunding (ECF). It is an information technology-based innovation that offers stocks or investments. It has developed in various countries including Indonesia. Based on Article 1 clause (1) of the Regulation of the Financial Service Authority (RFSA) No.37/POJK.04/2018, equity crowdfunding is a service that offers shares carried out by issuers to sell their stocks directly to the investors through an opened electronic network system. ${ }^{4}$ Various fintech equity crowdfunding companies develop to offer applications that may become the intermediary between investors and startup companies that require funding, such as Santara, CrowdDana, Bizhare, Danasaham, and Land-X. These sites have obtained licenses from the Financial Service Authority (FSA) to become official platforms for equity crowdfunding activities. These equity crowdfunding platforms allow easy and efficient online investments. The crowdfunding services with the equity crowdfunding system give positive impacts in increasing the Indonesian economy, especially to support business actors that experience financial crises.

As an institution that aims to individually supervise and manage the traffic of the financial service sector, ${ }^{5}$ the Financial Service Authority (FSA) through the RFSA No. 37/POJK.04/2018 on a Crowdfunding Service through the Offering of Information Technology-Based Shares (Equity Crowdfunding) that was applied on December $31^{\text {st }}, 2018$ provided systematic legal protection to manage and to accommodate the interests of the users and to protect them. In its development, the law on equity crowdfunding is deemed to not be able to fulfil the funding needs for micro, small, and medium enterprises (MSMEs), ${ }^{6}$ considering that in the RFSA No. 37/POJK.04/2018, the MSMEs may only be in the form of Limited Companies. Article 33 of the RFSA No. 37/POJK.04/2018 states, "Issuers must be in the form of Limited Companies."7. To expand the scope of the issuer and other stock-offering activities in the crowdfunding services, the FSA issued the RFSA No. 57/POJK.04/2020 to perfect the RFSA 37/POJK.04/2018. Equity crowdfunding is hereinafter called Securities Crowdfunding. Article 1 of the RFSA No. 57/POJK.04/2020 ${ }^{8}$ states that in its development, securities crowdfunding is hoped to

\footnotetext{
${ }^{2}$ Kustoro Budiarta, Sugianta Ovinus, Ginting dan Janner Simartama, "Ekonomi dan Bisnis Digital (Economy and Digital Business)', Medan, Penerbit Yayasan Kita Menulis, 2020, pg.2

${ }^{3}$ Kristian Kartini, Rinsofat Naibaho, Uton Utomo, "Tinjauan Yuridis Regolatory Sandbox Terhadap Mekanisme Teknologi Finansial (Fintech) di Indonesia (The Juridical Analysis on Regulatory Sandbox towards the Financial Technology Mechanism in Indonesia)", Patik:Jurnal Hukum, 2020, Vol.09 No.02, hal. 115

${ }^{4}$ Otoritas Jasa Keuangan, Peraturan Otoritas Jasa Keuangan Republik Indonesia Nomor.37/POJK.04/2018 tentang Layanan Urun Dana Melalui Penawaran Saham Berbasis Teknologi Informasi (Equity Crowdfunding), (Financial Service Authority (FSA) through the RFSA No. 37/POJK.04/2018 on a Crowdfunding Service through the Offering of Information TechnologyBased Shares (Equity Crowdfunding)), Article 1

${ }^{5}$ FAQ Financial Service Authority accessed on https://www.ojk.go.id/id/Pages/FAQ-otoritas-jasa-keuangan.aspx 01 November 2021

${ }^{6}$ Andini Astarianti \& Ukhti Dyandra Sofiani, "Perspektif Hukum Mengenai Penggunaan Securities Crowdfunding Pada Masa Pemulihan Ekonomi Akibat Pandemi (Legal Perspective on the Use of Securities Crowdfunding During The Economic Recovery Due To The Pandemic)", Jurnal Hukum Lex Generalis, 2021, Vol.2 No.8, hal. 616

${ }^{7}$ (Financial Service Authority (FSA) through the RFSA No. 37/POJK.04/2018 on a Crowdfunding Service through the Offering of Information Technology-Based Shares (Equity Crowdfunding)), Article 33

${ }^{8}$ Financial Service Authority (FSA) through the RFSA on the Offering of Stocks through Information Technology-Based Crowdfunding Service No. 57/POJK.04/2020.
} 
encourage the recovery of the Indonesian economy, especially the MSMEs at various sectors, such as property, retail, food and beverage, etc. Business actors may obtain funding with great profit through the securities crowdfunding services. ${ }^{9}$

There was a transitional provision in the RFSA No. 57/POJK.04/2020 which regulated that equity crowdfunding organizers must apply for the permit of expansion. It has even applied the grace period and its sanctions. In its development, some equity crowdfunding platforms that have obtained permits from the FSA still have difficulties expanding in obtaining permits from the FSA to become securities crowdfunding platforms. Article 88 clause 1 of the RFSA No. 57/POJK.04/2020 ${ }^{10}$ stated that there is the obligation to apply for the expansion of the equity crowdfunding platform permit to become a securities crowdfunding platform with the maximum limit of one year after the issuing of the RFSA No. 57/POJK.04/2020. In Article 89 of the RFSA No. 57/POJK.04/2020, ${ }^{11}$ there are stipulations on the sanctions for the equity crowdfunding platform companies who fail to propose the expansion of the equity crowdfunding platform permit in one year. If they fail to do so, they will be stated as an unlicensed business platform or a business activity and that they will not be supervised by the FSA.

In its development, from the five licensed equity crowdfunding platforms, only one has fulfilled the requirements and obtained the license from the FSA to expand the scope to become a securities crowdfunding platform, namely Bizhare. Then, up to the end of December 2020, only 129 issuers or MSME actors have used the ECF platform at the four organizing platforms from a total of 64 million MSMEs in Indonesia. ${ }^{12}$ It means that they are not yet effective and it seems that the government's aim to increase the economy through crowdfunding services to business owners to increase the productivity of MSMEs in Indonesia will not be achieved soon enough.

Referring to the description above, it is interesting to discuss the concerns on the protection of the equity crowdfunding activity through the issuing of the RFSA No. 57/POJK.04/2020 transitional provision from the equity crowdfunding activity to the securities crowdfunding. It is also interesting to analyze the expansion permit proposal that is carried out by equity crowdfunding platforms. This is because the government's aim to increase the Indonesian economy through the issuing of the RFSA may bring loss to the platforms. Thus, this article will provide an answer to the issue of the legal protection of the equity crowdfunding service based on the RFSA No. 57/POJK.04/2020 and is the stipulation deemed as correct, considering that there are still great risks that occur to information technology-based services.

\section{Literature Review}

\section{Transitional Provisions}

A Transitional Provision is a type of stipulation in constitutional regulation. It is a legal stipulation that functions to make sure that no one is harmed by the change of the stipulations in constitutional regulation. The Transitional Provisions contain norms that stipulate when the authority granted by the new constitutional regulations must apply. It is crucial as it concerns the stipulation that constitutional regulations apply to the future and they cannot subside ${ }^{13}$.

\footnotetext{
9 Asosiasi Layanan Urun Dana Indonesia (ALUDI/Association of the Crowdfunding Service in Indonesia), 2021, "Recovering the Indonesian Economy through SCF”, accessed on https://aludi.id/uploads/artikel/PDF_SCF_31_Mei.pdf 01 November 2021

${ }^{10}$ Financial Service Authority (FSA) through the RFSA on the Offering of Stocks through Information Technology-Based Crowdfunding Service No. 57/POJK.04/2020 Article 88 clause 1

${ }^{11}$ Financial Service Authority (FSA) through the RFSA on the Offering of Stocks through Information Technology-Based Crowdfunding Service No. 57/POJK.04/2020 Article 89

12 ANTARANEWS.com, 2021, "OJK: Pasca diterbitkannya POJK 57, dana himpunan SCF naik persen (FSA: After issuing the RFSA 57, the crowdfunding collected in SCF increased by 52,1\%)", accessed from https://www.antaranews.com/berita/2303898/ojk-pasca-diterbitkannya-pojk-57-dana-himpunan-scf-naik-521-persen\#mobile-nav 31 October 2021

13 Sri Hariningsih, "Ketentuan Peralihan dalam Peraturan Perundang-undangan (The transitional provisions in the constitutional regulations)”, Jurnal Legislasi Indonesia (Indonesian journal of legislation), 2009, Vol 6 No. 4, p. 596, accessed
} 


\section{Crowdfunding}

Crowdfunding is a form of funding from some people to those who need money to develop their business. This activity was first initiated and developed in the US. It was then followed by other countries such as the UK, Italy, Germany, and also Indonesia. ${ }^{14}$ Valanciene and Jegeleiciute suggest that Crowdfunding is a method that can connect entrepreneurs and investors through an internet-based intermediary. ${ }^{15}$ Crowdfunding is said to be a technique of funding business projects or units that extensively involve society. ${ }^{16}$ However, due to the lack of Indonesian people's literacy level on crowdfunding, there is lateness in the development of crowdfunding activities and there is only a minimum level of participation from society. In 2008, crowdfunding developed rapidly due to the global crisis that decreased people's trust in the banking industry. ${ }^{17}$ This caused the rampant creation of legal and illegal equity crowdfunding platforms.

Crowdfunding develops and it has several business models. First, Donation-Based crowdfunding is popular for social and charity-based crowdfunding. It does not expect compensation from the project owner, such as the Kitabisa.com platform. This is the only surviving platform in Indonesia that actively carries out donation-based crowdfunding. Second, Reward-Based crowdfunding that acts in projects that offer compensation in the form of services or rights in the creative industry, includes games and their features, movies, and comics. An example of this type of crowdfunding's platform is wujudkan.com. ${ }^{18}$ Third, Debt-Based crowdfunding provides loans with the compensation of interests to the investors that act as creditors and Micro, Small, and Medium Enterprises (MSMEs) or start-ups as the debtors. ${ }^{19}$ Fourth, Equity Crowdfunding provides funding to developing or struggling MSMEs or start-ups that require funding. The equity of the stocks is owned by investors from the funding. Investors obtain profit from the business project or unit according to the percentage of the funding they provided. Equity Crowdfunding platforms include Santara, Land-X, Crowddana, Bizhare, and Danasaham.

\section{Equity Crowdfunding}

Equity is defined as an ownership right to a business or a venture based on the amount of capital one has provided, like shares. Then, crowdfunding is defined as the activity of fundraising. Thus, it can be concluded that equity crowdfunding is a type of crowdfunding for businesses by raising money from many people in the form of shares. ${ }^{20}$ Equity Crowdfunding has a special regulation as issued by the Financial Service Authority, namely Regulation of the Financial Service Authority No.37 POJK.04/2018. This regulation defines Equity Crowdfunding is a crowdfunding service that offers shares that are carried

fromhttps://ejurnal.peraturan.go.id/index.php/jli/article/viewFile/335/219\#: :text=Ketentuan\%20Peralihan\%20(Transitional\%20

Provision\%E2\%80\%93Overgangs, dalam\%20suatu\%20Peraturan\%20Perundang\%2Dundangan. on 22 December 2021

${ }^{14}$ Ismi Hariyani \& Cita Yustisia Serfiyani, 2015, "Perlindungan Hukum Sistem Donation-Based Crowdfunding pada Pendanaan Industri Kreatif di Indonesia (The Legal Protection for the Donation-Based Crowdfunding System in the Indonesian Creative Industry)", accessed from https://e-jurnal.peraturan.go.id/index.php/jli/article/viewFile/417/297 1 November 2021

${ }^{15}$ Pas Ingrid Pamesti \& Bagas Heradhayksa, "Kepastian Hukum Mekanisme Equity Crowdfunding melalui Platform Santara.id sebagai Sarana Investasi (The Legal Certainty for Equity Crowdfunding Mechanism through the Santara.id Platform as an Investment Instrument)”, Jurnal Hukum Ekonomi Islam, 2020, Vol.4 No.1, pg. 25

16 Dhoni Siamsyah Fadillah Akbar, 2015, "Konsep Crowdfunding untuk Pendanaan Infrastruktur di Indonesia (The Crowdfunding Concept to Fund the Indonesian Infrastructure)", accessed from https://www.kemenkeu.go.id/publikasi/artikeldan-opini/konsep-crowdfunding-untuk-pendanaan-infrastruktur-di-indonesia/ 01 November 2021

17 Wasiaturrahma, 2019, "Fintech dan Prospek Bisnis Koperasi Syariah (Fintech and the Business Prospect of Sharia Cooperatives)”, Surabaya: Scopindo, hal.42

${ }^{18}$ Nugroho \& Rachmaniyah, "Fenomena Perkembangan Crowdfunding di Indonesia (The Phenomenon of the Development of Crowdfunding in Indonesia)”, Jurnal Ekonomi Universitas Kadiri, 2019, Vol. 4 No. 1, hal. 40

${ }^{19}$ Pramesti, Pas Inggrid \& Bagas Headhayksa, "Kepastian Hukum Mekanisme Equity Crowdfunding melalui Platform Santara.id sebagai Sarana Investasi (The Legal Protection for Equity Crowdfunding Mechanism through the Santara.id Platform as an Investment Instrument)”, Jurnal Hukum Ekonomi Islam, 2020, Vol. 4 No. 1, pg. 26

20 Channel Youtube Joinan, 2020, "Securities Crowdfunding (Joinan)", accessed from https://www.youtube.com/watch?v=dSm5efBWMqA on 01 November 2021 
out by the issuer by selling stocks directly to investors through a public electronic system. ${ }^{21}$ Equity Crowdfunding has an important role in the economic development during the Covid-19 pandemic as it helps start-ups or MSMEs that struggle in obtaining funding and those that are threatened to become bankrupt. Social network and equity crowdfunding platforms may open new opportunities in collecting funds for businesses and they allow non-professional investors to place their funds without an intermediary financial system. ${ }^{22}$

According to Novia and Nahdlotul, equity crowdfunding is also defined as a mechanism of collecting funds from a group of people with various interests to support a business or other activities. ${ }^{23}$ Crowdfunding generally means advertising one's project or venture that require funding online to collect small amounts of money from an undefined large number of people. ${ }^{24}$ It is a service that collects funds from the general society for start-up projects, micro-businesses, artists, or social activists that have difficulties obtaining loans from financial institutions. ${ }^{25}$ From the previous explanations, it can be concluded that crowdfunding is a small action that could develop into something great. It is carried out with the effort to raise some money from the public to fund a project from parties that have difficulties obtaining funds.

These are some equity crowdfunding platforms that have obtained licenses from the Financial Service Authority in Indonesia.

Table 1 . The equity crowdfunding platforms that are officially licensed by the Financial Service Authority in Indonesia

\begin{tabular}{|c|c|c|c|c|}
\hline No & $\begin{array}{l}\text { Name of } \\
\text { platform }\end{array}$ & Name of Company & Website & License Number \\
\hline 1 & Santara & $\begin{array}{l}\text { PT. Santara Daya } \\
\text { Inspiratama }\end{array}$ & https://santara.co.id/ & KEP-59/D.04/20196 \\
\hline 2 & Bizhare & $\begin{array}{l}\text { PT. Investasi Digital } \\
\text { Nusantara }\end{array}$ & https://www.bizhare.id & KEP-71/D.04/2019 \\
\hline 3 & $\begin{array}{c}\text { CrowdDan } \\
\text { a } \\
\end{array}$ & $\begin{array}{c}\text { PT. Crowddana } \\
\text { Teknologi Indonesia } \\
\end{array}$ & https://crowddana.id/ & KEP-93/D.04/201928 \\
\hline 4 & Land-X & $\begin{array}{l}\text { PT. Numex Teknologi } \\
\text { Indonesia }\end{array}$ & https://landx.id/ & KEP-68/D.04/2020 29 \\
\hline 5 & $\begin{array}{c}\text { DanaSaha } \\
\mathrm{m}\end{array}$ & $\begin{array}{l}\text { PT. Dana Saham } \\
\text { Bersama }\end{array}$ & $\begin{array}{c}\text { https://danasaham.co.i } \\
\mathrm{d} /\end{array}$ & KEP-16/D.04/202130 \\
\hline
\end{tabular}

\footnotetext{
${ }^{21}$ Financial Service Authority (FSA) through the RFSA No. 37/POJK.04/2018 on a Crowdfunding Service through the Offering of Information Technology-Based Shares (Equity Crowdfunding)

${ }^{22}$ Kuti, Monika, Zsolt Bedo, Dorottya Geiszl, "Equity-based Crowdfunding”, Financial and Economic Review, 2017, Vol. 16 pg. 193

${ }^{23}$ Novia \& Nahdlatul, "Legal Protection for Investors in Crowdfunding Services Through Information Technology Offers (Equity Crowdfunding)”, Syiah Kuala Law Journal, 2020, Vol.4 No.2, Hal. 158

${ }^{24}$ Min seop yun, "A Legal Study on the Crowdfunding as Means of Obtaining Capital”, Korean Journal of Business Law, 2012, Vol.26 No.2, pg.188

${ }^{25}$ Seong \& Hye Hwal, “A Study on the Regulatory Framework for the Equity Crowdfunding”, Korean Journal of Securities Law, 2013, Vol.14 No.2, pg.393

${ }^{26}$ Santara, accessed from https://www.santara.co.id/tentang-santara on 01 November 2021

${ }^{27}$ Bizhare, accessed from https://www.bizhare.id/syarat-ketentuan-umum-kebijakan-privasi on 01 November 2021

${ }^{28}$ Crowddana, accessed from https://faqs.crowddana.id/id/article/cara-kerja-crowddana-p1rzjc/ on 01 November 2021

${ }^{29}$ Kontan.co.id, 2021, "OJK berikan izin usaha equity crowdfunding kepada Numex Teknologi Indonesia (FSA gives an equity crowdfunding business permit to Numex Teknologi Indonesia)", accessed from https://keuangan.kontan.co.id/news/ojk-berikanizin-usaha-equity-crowdfunding-kepada-numex-teknologi-indonesia on 01 November 2021

${ }^{30}$ Danasaham, accessed from https://danasaham.co.id/news.html?id=1 on 01 November 2021
} 


\section{Platform Equity Crowdfunding Parties According to Regulation of FSA No. 37/POJK.04/2018 and Regulation of FSA No. 57/POJK.04/2020}

The FSA issued a regulation on the Information Technology-Based Crowdfunding Service through the Offering of Shares (Equity Crowdfunding) that regulates the concerning parties, the rights of each party, the amount of funding, the requirements of a party, the risks, and the sanctions if there are violations in the equity crowdfunding activities. Three parties are involved in equity crowdfunding, as stipulated in RFSA No. 37/POJK.04/2018 on a Crowdfunding Service through the Offering of Information Technology-Based Shares (Equity Crowdfunding) and in the transitional provision, namely RFSA No. 57/POJK.04/2020 on the Offering of Stocks through the Information Technology-Based Crowdfunding Services. These parties are:

1. The Crowdfunding Service Organizers. Based on Article 1 clause (4) of the RFSA No. 37/POJK.04/2018, "organizers are Indonesian legal agencies that provide, manage, and operate a crowdfunding service." 31 This is also stipulated in the transitional provision RFSA No. 57/POJK.04/2020 Article 1 clause (5) that perfects the law on equity crowdfunding.

These are the requirements to become an organizer in an equity crowdfunding service, based on the RFSA No. 37/POJK.04/2018:

a) Organizers that will undergo equity crowdfunding services must obtain a business permit from the Financial Service Authority. ${ }^{32}$ (Article 7 of the RFSA on Equity Crowdfunding).

b) Organizers must be registered as electronic system organizers in the Ministry that organize governmental affairs in the information and communication sector. ${ }^{33}$ (Article 8 of the RFSA on Equity Crowdfunding).

c) Organizers must provide, manage, and operate the Crowdfunding Services for Users. The Organizers may cooperate with information technology-based financial service organizers according to the constitutional regulations. ${ }^{34}$ (Article 9 of the RFSA on Equity Crowdfunding).

d) The organizers are Indonesian legal agencies that are in the form of Limited Companies or Cooperatives. ${ }^{35}$ (Article 10 of the RFSA on Equity Crowdfunding).

e) In proposing a license, organizers must have their own capital of at least 2,5 billion rupiahs. ${ }^{36}$ (Article 12 of the RFSA on Equity Crowdfunding).

f) Organizers must have expert human resources or those with backgrounds in information technology to review the Issuers. ${ }^{37}$ (Article 13 of the RFSA on Equity Crowdfunding).

g) Organizers must use an escrow account to banks that are used to obtain the proceeds from the stock offers from the crowdfunding services. ${ }^{38}$ This aims to fulfil the stipulation that prohibits organizers to crowdfund using the organizers' bank accounts.

\footnotetext{
${ }^{31}$ Financial Service Authority (FSA) through the RFSA No. 37/POJK.04/2018 on a Crowdfunding Service through the Offering of Information Technology-Based Shares (Equity Crowdfunding) Chapter 1 Article 1 clause 4

${ }^{32}$ Financial Service Authority (FSA) through the RFSA No. 37/POJK.04/2018 on a Crowdfunding Service through the Offering of Information Technology-Based Shares (Equity Crowdfunding) Chapter 1 Article 7

${ }^{33}$ Financial Service Authority (FSA) through the RFSA No. 37/POJK.04/2018 on a Crowdfunding Service through the Offering of Information Technology-Based Shares (Equity Crowdfunding) Chapter 1 Article 8

${ }^{34}$ Financial Service Authority (FSA) through the RFSA No. 37/POJK.04/2018 on a Crowdfunding Service through the Offering of Information Technology-Based Shares (Equity Crowdfunding) Chapter 1 Article 9

${ }^{35}$ Financial Service Authority (FSA) through the RFSA No. 37/POJK.04/2018 on a Crowdfunding Service through the Offering of Information Technology-Based Shares (Equity Crowdfunding) Chapter 1 Article 10

${ }^{36}$ Financial Service Authority (FSA) through the RFSA No. 37/POJK.04/2018 on a Crowdfunding Service through the Offering of Information Technology-Based Shares (Equity Crowdfunding) Article 12

${ }^{37}$ Financial Service Authority (FSA) through the RFSA No. 37/POJK.04/2018 on a Crowdfunding Service through the Offering of Information Technology-Based Shares (Equity Crowdfunding) Article 13

${ }^{38}$ Financial Service Authority (FSA) through the RFSA No. 37/POJK.04/2018 on a Crowdfunding Service through the Offering of Information Technology-Based Shares (Equity Crowdfunding) Article 48
} 
The organizers of this activity have the role to create a place to connect the equity crowdfunding parties in the equity crowdfunding platform. The stipulations to become crowdfunding service organizers are also contained in the transitional provision, namely the RFSA No. 57/POJK.04/2020 with additional perfecting stipulations, as added in Article 9 as follows: ${ }^{39}$

a) Organizers must be in the form of a limited company legal body. It can be established and owned by Indonesian citizens and Indonesian legal bodies.

b) Organizers in the form of a limited company legal body can be established and owned by foreign citizens and/or foreign legal bodies with either direct or indirect shared ownership with a maximum of $49 \%$.

2. The issuers of a crowdfunding service are an Indonesian Legal Body with the form Limited Company that offer shares through the Organizers. ${ }^{40}$ The requirements for issuers are stipulated in RFSA No. 37/POJK.04/2018:

a) Issuers must be in the form of a Limited Company.

b) Issuers are not companies that are directly or indirectly controlled by a business group or a conglomeration, it must not be a public company or a public subsidiary. It must not be a company with wealth that is more than Rp10.000.000.000,00 (ten billion rupiahs) excluding land and buildings.

c) Issuers must submit documents and/or information to the organizers according to the stipulations of the RFSA No. 37/POJK.04/2018.

In the transitional provision, namely the RFSA No. 57/POJK.04/2020 there was a change of the requirement so that issuers can include all groups. So, it is not only limited to Limited Companies. The stipulations are as follows:

"The Issuer is an Indonesian business entity with the legal entity form or other business entities that issue stocks through the crowdfunding services." 41

3. Crowdfunding Service Investors are the party that buys shares of the issuers through the organizers. The criteria for investors in the crowdfunding service according to the RFSA No. 37/POJK.04/2018: ${ }^{42}$

a) All investors with an annual income of up to Rp500.000.000,00 (five hundred million rupiahs) can buy shares as much as $5 \%$ from their annual income.

b) All investors with an annual income of more than Rp500.000.000,00 (five hundred million rupiahs) can buy shares at most $10 \%$ of their annual income.

The criteria of limit stipulated in the RFSA No. 37/POJK.04/2018 do not apply to investors with investment experiences and proof of a two-year stock account ownership before the offering of the shares. $^{43}$

There are some weaknesses of the Regulations of the Financial Service Authority on equity crowdfunding. This encouraged the FSA to perfect its regulations and changed equity crowdfunding into

\footnotetext{
${ }^{39}$ Financial Service Authority (FSA) through the RFSA No. 37/POJK.04/2018 on a Crowdfunding Service through the Offering of Information Technology-Based Shares (Equity Crowdfunding) Article 9

${ }^{40}$ Financial Service Authority (FSA) through the RFSA No. 37/POJK.04/2018 on a Crowdfunding Service through the Offering of Information Technology-Based Shares (Equity Crowdfunding) Chapter 1 Article 7

${ }^{41}$ Financial Service Authority (FSA) through the RFSA on the Offering of Stocks through Information Technology-Based Crowdfunding Service No. 57/POJK.04/2020 Chapter 1 Article 1 clause 7

${ }^{42}$ Financial Service Authority (FSA) through the RFSA No. 37/POJK.04/2018 on a Crowdfunding Service through the Offering of Information Technology-Based Shares (Equity Crowdfunding) Article 42 clause 2

${ }^{43}$ Financial Service Authority (FSA) through the RFSA No. 37/POJK.04/2018 on a Crowdfunding Service through the Offering of Information Technology-Based Shares (Equity Crowdfunding) Article 42 clause 3
} 
securities crowdfunding. This concept was first rolled out by the government through Airlangga Hartarto, the Minister of the Coordinator for the Economic Sector who officially launched the Securities Crowdfunding activity during the trade opening in the Indonesia Stock Exchange on January $4^{\text {th }}, 2021 .^{44}$

\section{Research Method}

This paper uses the normative legal research method. It uses secondary data by emphasizing and holding on to the juridical aspects. The research problem is analyzed using constitutional regulations and literary materials that concerns the problem. In this paper, the researcher analyzes legal norms, legal principles contained in constitutional regulations and data on the crowdfunding service activity through information technology-based offer of stocks (equity crowdfunding), analyzed based on the RFSA No. 57/POJK.04/2020.

\section{Results and Discussion}

\section{The Urgency of a Legal Protection for Equity Crowdfunding Service Users Based on the RFSA No. 57/POJK.04/2020}

There is a great increase in the development of equity crowdfunding in the digital era in Indonesia. Thus, the government issued a policy from the RFSA No. /POJK.04/2018 that required perfecting. Its perfected regulation is the RFSA No. 57/POJK.04/2020. In Chapter XII, the regulation stipulated the transitional provisions for the organizers to expand their equity crowdfunding business or services to securities crowdfunding. The stipulations are as follows: ${ }^{45}$

1) Organizers that have obtained a permit as equity crowdfunding organizers before the issuing of the RFSA No. 57/POJK.04/2020 must expand the business activity by adapting to the fulfillment of requirements and by applying to the Financial Service Authority at most 1 (one) year after the issuing of the RFSA No. 57/POJK.04/2020.

2) The organizers that have submitted the application for permits and after the application of the RFSA No. 57/POJK.04/2020 has not obtained the permit from the FSA must:

a) Follow the permit requirements as stipulated in RFSA No. 37/POJK.04/2018 on equity crowdfunding; or

b) Adapt to the permit requirements as stipulated in the RFSA No. 57/POJK.04/2020.

3) If organizers fail to submit an application for a permit at most in a year, the organizer's business activity is deemed unlicensed and is no longer supervised by the FSA. ${ }^{46}$

There is no further explanation on the equity crowdfunding organizers who must expand their business activity to become securities crowdfunding organizers and the time limit of applying the permit expansion to the FSA. In the transitional provisions contained in the RFSA No. 57/POJK.04/2020 the equity crowdfunding organizing party have at most one year to submit their application for the permit expansion to the FSA. This may lead to the decrease of the system or mechanism in the crowdfunding

\footnotetext{
${ }^{44}$ FSA Press Conference, 2021, "Press Conference: Encouraging MSMEs to use the stock market, FSA launched Securities Crowdfunding at the opening of the Indonesian stock exchange 2021", accessed from https://www.ojk.go.id/id/berita-dankegiatan/siaran-pers/Pages/Siaran-Pers-Dorong-UKM-Manfaatkan-Pasar-Modal,-OJK-Luncurkan-Securities-Crowdfunding.aspx on 02 November 2021

${ }^{45}$ Financial Service Authority (FSA) through the RFSA on the Offering of Stocks through Information Technology-Based Crowdfunding Service No. 57/POJK.04/2020 Chapter XII Article 88

${ }^{46}$ Financial Service Authority (FSA) through the RFSA on the Offering of Stocks through Information Technology-Based Crowdfunding Service No. 57/POJK.04/2020 Article 89
} 
service activity. The lack of plans may result in the unfulfillment of the users' rights. It may lead the users to experience loss in equity crowdfunding activities. ${ }^{47}$

The lack of further explanation on the organizers of the equity crowdfunding that have submitted an application for a permit but has not obtained it and that may still follow the permit requirements in the RFSA No. 37/POJK.04/2018. Meanwhile, the stipulations stated in the closing of Chapter XIII of the RFSA No. 57/POJK.04/2020 is as follows:

"When the RFSA No. 57/POJK.04/2020 on securities crowdfunding start to apply, the RFSA No. 37/POJK.04/2018 on equity crowdfunding (the Republic of Indonesia's 2018 Fascicle No. 262, the Republic of Indonesia's Additional Fascicle No. 6288) is revoked and it no longer applies. " 48

If there are no legal certainties on the organizers that have submitted a permit to expand the scope to become a securities crowdfunding platform but have not obtained a permit from the FSA, the FSA should give further explanation and legal certainty on the role of the organizers, so that they are not confused by the chaos in the service mechanism of the organizing party.

Referring to the explanations above, in submitting for an application, there needs to be an additional grace period or a period to apply for business expansion. It should be added with 3 or 4 years, as companies or equity crowdfunding service organizers certainly require further analysis on the additional stipulations that perfect the RFSA No. 37/POJK.04/2018 in the RFSA No. 57/POJK.04/2020 in expanding the business activity of the equity crowdfunding platform to become a securities crowdfunding platform. With additional stocks, bonds, debentures, and other stipulations that are responsibilities of the organizers, the organizing company need to be well-prepared so that platforms are according to the stipulations of the RFSA No. 57/POJK.04/2020. It is hoped that there are no risks that disadvantage the investors, issuers, or the organizers.

Seeing the number of issuers available, namely 129 issuers in 4 years of the crowdfunding service program, added with the difficulties the equity crowdfunding services face to expand and become a securities crowdfunding platform, and also the sanctions they face if they are deemed as unlicensed and that they no longer obtain supervision from the FSA if they fail to apply at most one year since the issuing of the new law, it is shown that there are many issues that the crowdfunding organizers face to survive. Another issue includes the lack of further explanation on the stipulations on the permit expansion for equity crowdfunding organizers. The sanctions for the equity crowdfunding platform organizers should be revoked so that the organizers may still run their business while carrying out analyses to expand their platforms without operational failure and the lack of quality information delivered by the organizers ${ }^{49}$ due to their lack of understanding of the new transitional provision. The operational failure may be in the form of an error platform due to the lack of the organizers' preparedness in renewing or in expanding the mechanism, and also the actions of hackers that disturb the offering activity of the various stocks in the securities crowdfunding.

If the organizers' operations do not run well, the rights and obligations of the users are questioned. The sanctions are given in RFSA No. 57/POJK.04/2020 will bring loss to the organizers, the users, or the Indonesian economy, as many organizers are not ready enough to expand their crowdfunding service activity from equity crowdfunding to become securities crowdfunding. The decrease of crowdfunding service users will inhibit the government's plan to increase the Indonesian economy

\footnotetext{
${ }^{47}$ Zevanya \& Dona, "Tantangan dan Hambatan Otoritas Jasa Keuangan Dalam Pengawasan Equity Crowdfunding (Challenges and Obstacles of the FSA in Supervising the Equity Crowdfunding)", Jurnal Hukum dan Pembangunan Ekonomi, 2019 , Vol 7 No.2, hal. 304

${ }^{48}$ Financial Service Authority (FSA) through the RFSA on the Offering of Stocks through Information Technology-Based Crowdfunding Service No. 57/POJK.04/2020 Article 91

49 Na'im \& Kukuh, "Urgensi Penerapan Regulatory Sandbox Oleh Otoritas Jasa Keuangan Sebagai Upaya Perlindungann Hukum Bagi Pemodal Equity Crowdfunding (Urgency The RegulatorySandbox By Authority Financial Services As a Legal Protection For Financier Equity Crowdfunding)", Jurnal de Jure, 2020, Vol. 12 No.1, pg. 60
} 
through the crowdfunding program for MSMEs. Thus, the FSA needs to review the stipulations in the transitional provision chapter of the RFSA No. 57/POJK.04/2020 to provide further explanation and legal certainty to the organizers of the crowdfunding service platforms in expanding their business. After the explanation is provided, it is then fitting for them to apply sanctions on the organizers' platform expansion if required.

\section{Conclusion}

Equity crowdfunding is a crowdfunding service through the offering of information technologybased stocks to help society or beginner business actors in developing their business. Equity crowdfunding also has a role to increase the Indonesian economy. There are some issues in the transitional provision thus there are concerns that it will inhibit the equity crowdfunding services. The crowdfunding organizers are obliged to expand their equity crowdfunding activity to become securities crowdfunding with a maximum limit of one year. The limited time makes the equity crowdfunding organizers face troubles in obtaining the permit. There is also the stipulation that if the securities crowdfunding regulation has been issued, the equity crowdfunding regulations will be revoked. This leads to the lack of legal certainty to licensed equity crowdfunding organizers who are not yet ready to expand their crowdfunding services. The sanctions make the organizer worried about expanding their business in such a short period.

\section{References}

Otoritas Jasa Keuangan, Peraturan Otoritas Jasa Keuangan Republik Indonesia Nomor.37/POJK.04/2018 tentang Layanan Urun Dana Melalui Penawaran Saham Berbasis Teknologi Informasi (Equity Crowdfunding)

Otoritas Jasa Keuangan, Peraturan Otoritas Jasa Keuangan Republik Indonesia Tentang Penawaran Efek melalui Layanan Urun Dana Berbasis Teknologi Informasi Nomor 57/POJK.04/2020

Kamus Besar Bahasa Indonesia

Kustoro Budiarta, Sugianta Ovinus, Ginting dan Janner Simartama, 2020, "Ekonomi dan Bisnis Digital”, Medan, Penerbit Yayasan Kita Menulis

Suratman H. \& Philips Dullah, 2013, "Metode Penelitian Hukum”, Bandung, CV. Alfabeta

Wasiaturrahma, 2019, “Fintech dan Prospek Bisnis Koperasi Syariah”, Surabaya: Scopindo

Andini Astarianti \& Ukhti Dyandra Sofiani, 2021, "Perspektif Hukum Mengenai Penggunaan Securities Crowdfunding Pada Masa Pemulihan Ekonomi Akibat Pandemi (Legal Perspective on the Use of Securities Crowdfunding During The Economic Recovery Due To The Pandemic)', Jurnal Hukum Lex Generalis, Vol.2 No.8

Kristian Kartini, Rinsofat Naibaho, Uton Utomo, 2020, “Tinjauan Yuridis Regolatory Sandbox Terhadap Mekanisme Teknologi Finansial (Fintech) di Indonesia”, Patik:Jurnal Hukum, Vol.09 No.02

Kuti, Monika, Zsolt Bedo, Dorottya Geiszl, 2017, "Equity-based Crowdfunding”, Financial and Economic Review, Vol. 16

Min seop yun, 2012, "A Legal Study on the Crowdfunding as Means of Obtaining Capital”, Korean Journal of Business Law, Vol.26 No.2 
Na'im \& Kukuh, 2020, “Urgensi Penerapan Regulatory Sandbox Oleh Otoritas Jasa Keuangan Sebagai Upaya Perlindungann Hukum Bagi Pemodal Equity Crowdfunding ( Urgency The RegulatorySandbox By Authority Financial Services As a Legal Protection For Financier Equity Crowdfunding) ', Jurnal de Jure, Vol. 12 No.1

Novia \& Nahdlatul, 2020, "Legal Protection For Investors In Crowdfunding Services Through Information Technology Offers (Equity Crowdfunding)”, Syiah Kuala Law Journal, Vol.4 No.2

Nugroho \& Rachmaniyah, 2019, “Fenomena Perkembangan Crowdfunding di Indonesia”, Jurnal Ekonomi Universitas Kadiri, Vol. 4 No. 1

Pas Ingrid Pamesti \& Bagas Heradhayksa, 2020, "Kepastian Hukum Mekanisme Equity Crowdfunding melalui Platform Santara.id sebagai Sarana Investasi”, Jurnal Hukum Ekonomi Islam, Vol.4 No.1

Pramesti, Pas Inggrid \& Bagas Headhayksa, 2020, "Kepastian Hukum Mekanisme Equity Crowdfunding melalui Platform Santara.id sebagai Sarana Investasi”, Jurnal Hukum Ekonomi Islam, Vol. 4 No. 1

Seong \& Hye Hwal, 2013, “A Study on the Regulatory Framework for the Equity Crowdfunding”, Korean Journal of Securities Law, Vol.14 No.2

Wayan Lasmawan, 2019, “Era Disrupsi dan Implikasinya bagi Reposisi Makna dan Praktek Pendidikan (Kaji Petik dalam Perspektif Elektik Sosial Analisis)” Jurnal Undiksha: jurnal media komunikasi pendidikan pancasila dan kewarganegaraan, vol 1

Zevanya \& Dona, 2019, “Tantangan dan Hambatan Otoritas Jasa Keuangan Dalam Pengawasan Equity Crowdfunding”, Jurnal Hukum dan Pembangunan Ekonomi, Vol 7 No.2

Aurelia Salsabila Putri dan Roni Zakaria, 2020, “Analisis Pemetaan E-Commerce Terbesar di Indonesia Berdasarkan Model Kekuatan Ekonomi Digital”, Seminar dan Konferensi Nasional IDEC

ANTARANEWS.com, 2021, "OJK: Pasca diterbitkannya POJK 57, dana himpunan SCF naik 52,1 persen”, diunduh dalam https://www.antaranews.com/berita/2303898/ojk-pasca-diterbitkannya-pojk57-dana-himpunan-scf-naik-521-persen\#mobile-nav Diakses pada tanggal 31 Oktober 2021

Asosiasi Layanan Urun Dana Indonesia (ALUDI), 2021, "Pemulihan Perekonomian Indonesia Melalui $S C F$ ”, diunduh pada https://aludi.id/uploads/artikel/PDF_SCF_31_Mei.pdf diakses pada tanggal 01 November 2021

Badan Penelitian dan Pengembangan SDM Puslitbang Aptika dan IKP, 2019, "PERKEMBANGAN EKONOMI DIGITAL DI INDONESIA, STRATEGI DAN SEKTOR POTENSIAL”, KOMINFO, Hal. 1, Diunduh pada https://balitbangsdm.kominfo.go.id/publikasi_665_3_230, tanggal 20 Agustus 2021.

Channel Youtube Joinan, 2020, "Securities Crowdfunding (Joinan)", diakses pada https://www.youtube.com/watch?v=dSm5efBWMqA tanggal 01 November 2021

Databoks, 2021, “Penetrasi Internet Indonesia Urutan ke-15 di Asia pada 2021", diunduh dalam Penetrasi Internet Indonesia Urutan ke-15 di Asia pada 2021 | Databoks (katadata.co.id) diakses pada tanggal 10 oktober 2021

Dhoni Siamsyah Fadillah Akbar, 2015, "Konsep Crowdfunding untuk Pendanaan Infrastruktur di Indonesia”, diakses pada https://www.kemenkeu.go.id/publikasi/artikel-dan-opini/konsepcrowdfunding-untuk-pendanaan-infrastruktur-di-indonesia/ tanggal 01 November 2021

FAQ Otoritas Jasa Keuangan diakses pada https://www.ojk.go.id/id/Pages/FAQ-otoritas-jasakeuangan.aspx tanggal 01 November 2021 
Graha Nurdian, 2021, “Data E-commerce Indonesia 2021 (Atur Strategi di Tahun 2021)”, dibuka dalam https://grahanurdian.com/e-commerce-indonesia-2021/ diakses pada tanggal 31 agustus 2021

IDX Channel, 2021, “Tumbuh Pesat, Jumlah Investor Saham di BEI Bertambah Satu Juta di 2021 ”, dibuka pada https://www.idxchannel.com/market-news/tumbuh-pesat-jumlah-investor-saham-di-beibertambah-satu-juta-di-2021 tanggal 11 oktober 2021

Ismi hariyani \& Cita Yustisia Serfiyani, 2015, "Perlindungan Hukum Sistem Donation Based Crowdfunsing pada Pendanaan Industri Kreatif di Indonesia (The Legal Protection Of The DonationBased Crowdfunding System On The Creative Indusry In Indonesia)", Diunduh pada https://ejurnal.peraturan.go.id/index.php/jli/article/viewFile/417/297 diakses paxda tanggal 1 November 2021

Kontan.co.id, 2021, "OJK berikan izin usaha equity crowdfunding kepada Numex Teknologi Indonesia", diakses pada https://keuangan.kontan.co.id/news/ojk-berikan-izin-usaha-equity-crowdfundingkepada-numex-teknologi-indonesia tanggal 01 November 2021

Siaran Pers OJK, 2021, "Siaran Pers: Dorong UKM Manfaatkan Pasar Modal, OJK Luncurkan Securities Crowdfunding. Pembukaan Perdagangan Bursa Efek Indonesia 2021”, diakses pada https://www.ojk.go.id/id/berita-dan-kegiatan/siaran-pers/Pages/Siaran-Pers-Dorong-UKMManfaatkan-Pasar-Modal,-OJK-Luncurkan-Securities-Crowdfunding.aspx

Bizhare, diakses pada https://www.bizhare.id/syarat-ketentuan-umum-kebijakan-privasi tanggal 01 November 2021

Crowddana, diakses pada https://faqs.crowddana.id/id/article/cara-kerja-crowddana-p1rzjc/ tanggal 01 November 2021

Danasaham, diakses pada https://danasaham.co.id/news.html?id=1 tanggal 01 November 2021

Santara, diakses pada https://www.santara.co.id/tentang-santara tanggal 01 November 2021

\section{Copyrights}

Copyright for this article is retained by the author(s), with first publication rights granted to the journal.

This is an open-access article distributed under the terms and conditions of the Creative Commons Attribution license (http://creativecommons.org/licenses/by/4.0/). 